\title{
RETROSPECTIVE ANALYSIS OF PEDAGOGICAL ASSISTANCE TO THE FORMATION OF PROFESSIONAL FLEXIBILITY OF CHIEF EXECUTIVES
}

\author{
L.A. Syuzyumova, syuzyumovala@gmail.com \\ South Ural State University, Chelyabinsk, Russian Federation
}

\begin{abstract}
In a modernized economy, there is an increased need for quality training of company's chief executives with a high level of professional flexibility. The aim of this study is to identify sociohistorical and theoretical-pedagogical preconditions for the formation and development of this quality in chief executives. This study analyses baseline data for further structuring and improving educational practices for professional flexibility formation. The understanding of the pedagogical assistance issue of professional flexibility formation of company's chief executives is based on a retrospective analysis. The historical retrospective is established on the following research subjects: "supplementary adult education"; "professional flexibility"; "pedagogical facilitation"; "targeting company's chief executives".

Representing the historiography of the problem the author reveals three historical periods: the 1 st one is from the beginning of the 60 s to the end of the 80 s of the XX century; the $2^{\text {nd }}$ period is from the end of the 80 s of the XX century to the beginning of the $2000 \mathrm{~s}$; the $3^{\text {rd }}$ period is from the beginning of the 2000 up to the present. The period before the $1960 \mathrm{~s}$ is regarded as a preparatory one. It created social, scientific, and practical conditions for pedagogical assistance to the development of professional flexibility among company's chief executives.

Keywords: retrospective analysis, historiography, period, initial point, key components of the problem, professional flexibility, formation, pedagogical assistance, company's chief executives.
\end{abstract}

\section{Introduction}

In modernized economic conditions, we can note the increased need for high-quality training of company's chief executives with a high level of professional flexibility, which, in turn, will help in solving professional and communicative problems. However, in practice, we detect an insufficient level of professional flexibility formation in company's chief executives. Despite the need, for training a high-level specialist, create professional and communication tools, as part of additional language training for company's chief executives (CCE), currently, there are not enough educational programs for the formation of professional competencies.

Similarly, this problem is required to analyze the socio-historical background of the problem pedagogical assistance in formation professional flexibility in company's chief executives and build the problem historiography.

The use of the process of the historical approach [33] to the study of the genesis of the withdrawn pedagogical problem will be fully justified. This means that it is necessary to choose and explain the choice of the "initial point" of its origin and determine the evolutionary periods.
According to I.O. Kotlyarova, G.N. Serikov [14], the basis for the historiography of scientific history was the research needed to understand the main positions accumulated by the scientific community and social practice. F.I. Valieva [28], T.V. Kornilova [13] described the components of professional flexibility of entrepreneurs, lawyers, and managers. Professional flexibility teachers became the subject of research by K.A. Avetisyan [3], E.S. Asmakovets [2] and others.

A.A. Derkach [7], studied the concept of "flexibility" and its relationship with the problem of the competence of civil servants. E.V. Artemyeva [1], A.M. Maltseva [16], T.Yu. Todysheva [27], defined various components of professional agility. The phenomenon of "flexibility" became a subject of study in the works of E.S. Ermakova [10], L.E. Zavalkevich [32], G.V. Zalevsky [29], Z.I. Kalmykova [12], A.N. Luk [15], A.M. Maltseva [16], N.F. Menchinskaya [18], T.Yu. Todysheva [27], A.A. Derkach [7, 8], D.N. Zavalishina [30], A.M. Maltseva [16], L.M. Mitina [19] and others. At present, the direction of personal and professional development, which include professional flexibility, is studied by numerous scientists 
J.P. Guilford, G.V. Zalevsky [29], L.M. Mitina [20], but the content and scope of the professional flexibility development of top managers have not been well understood. Nevertheless, all these studies have informed the development of the historiography of our problem.

The purpose of this study is to analyze the historical preferences accumulated in the past to identify positive and negative trends in the development of pedagogical assistance in the development of professional flexibility among top managers in learning a foreign language.

In particularly, we tried to solve the problem by answering the following question: What events within the retrospective analysis are significant for solving our problem?

Having considered the development of scientific knowledge on the issue of additional education, professional flexibility formation and the significance in self-determination of company's chief executives in Russia, the author's position on the development of necessary subjects to solve this research issue in a historical retrospective was formulated. With the use of these subjects, it was possible to clarify the priority references to these prerequisites, identifying what has been done and accumulated earlier by the scientific community to solve the identified problem.

We can conclude that by the early 1960s, each of the key components already existed in the social experience.

We have considered three main periods:

Period I - from the early 1960 s to the late 1980s;

Period II - from the late 1980 s to the early 2000s; sent.

Period III - from the early 2000 s to the pre-

Thus, the preparatory period created a certain basis for formulating the problem. During this period, the phenomenon under study is not the object of scientific analysis; its emergence is spontaneous in four directions.

The structure of this article is presented as an introductory part, which considers the stages of formation of this problem in terms of a retrospective analysis of the theoretical basis, which will allow further work in the framework of solving the problem of pedagogical assistance to the development of company's chief executives professional flexibility.

\section{Methods}

We have noted the importance of chronologically sequencing the development of this re- search problem and identifying the background to the research problem. We need to identify these prerequisites to analyze what has been done and accumulated by the scientific community to solve the identified problem. The main purpose of this study was to find the most suitable stages to identify the periods of the historical timeline of the formation of the problem of pedagogical assistance to the development of professional flexibility among CCEs, by comparing the existed events.

Since historiography is understood as a chronological and systematic body of information about its development [33]. It should also be noted that it is important to identify the sociopedagogical preconditions for the development of the scientific problem in order to identify and explain the 'starting points' of interest in the problem of our research.

The methodological basis for our pedagogical research in identifying socio-historical paradigms was based on:

- V.G. Grachyova, A.N., S.N. Nekrasov's research on pedagogy and education history; this analysis allowed us to understand the logic of identifying the main stages in the formation and development of domestic pedagogy;

- M.A. Barg, N.A. Berdyaev, S.L. Frank's civilizational approach, which studies the totality of all forms of human life activity in their historical development, allowed us to identify the boundaries of historical periods;

- the systemic approach studied by V.P. Bespalko [4] and G.N. Serikov [14], which reveals the interrelation of all components of the pedagogical system, allowed us to identify the main pedagogical ideas according to the components we identified;

- retrospective analysis of I.O. Kotlyarova and G.N. Serikov [14]. Was conducted by comparing the facts in terms of time and contribution to the problem solution, to identify the features that characterized the state of the problem solution in a historical retrospective.

Four major four key content components were identified:

- the formation of the problem of additional adult education in its historical aspect;

- issues of developing the problem of forming "professional flexibility";

- the problem of "pedagogical assistance" to the development of professional flexibility of top managers in teaching foreign languages;

- the problem of forming the target activity of a modern manager (top manager). 
In science, a "criterion" is usually defined as an essential property or an attribute of a phenomenon based on which it is evaluated.

We have noted the importance of the following criteria for further research:

1) scientific knowledge based on historical patterns;

2) scientific and practical achievements;

3) socially significant events of economic and political development.

It should be noted that in the next phase of the study, we noted trends in our problem, based on the importance of clarifying the identified key content components for retrospective analysis.

In conducting our research, we identified the following key actions:

- selection and preparation of the necessary background data for the analytical study, namely the research of the scientific literature;

- analysis of the selected raw data by components of interest for their subsequent structuring;

- interpretation of the analytical data obtained;

- concluding and based on the results of retrospective analysis.

Our comparative analysis ended with the synthesis of the author's position on the necessary criteria to determine the periods of occurrence of pedagogical ideas, problems, concepts, and theories, namely:

1) organizational and substantive foundations of the activity of institutions of additional education were identified;
2) the possibility of describing the processes of development of scientific and pedagogical knowledge based on the laws and regularities inherent in history was established;

3) the relationship between the development of pedagogical thought and various historical events that lead to changes in the life of society and the state was classified.

Finally, based on selected components, we analyzed the stages of formation of this problem and recorded the scientific and practical interest in all the above components of this study.

A graphical representation of the evolution the process of each component individually is shown in Fig. 1. The graphical representation of the development process of all the components clearly demonstrated the intersection of all four components at one point.

Three main periods were considered:

I period - from the beginning of the $60 \mathrm{~s}$ to the end of the $80 \mathrm{~s}$ of the XX century.

II period - from the end of the 80 s of the XX century to the beginning of the 2000s;

III period - from the beginning of the 2000 s to the present.

Thus, we will give a brief description of the genesis of the problem we have identified.

\section{Results}

The main aim of this research was to detect the most relevant periods to pinpoint the actual epochs of the problem of pedagogical assistance to the development of professional flexibility among managers, by comparing the existed events.

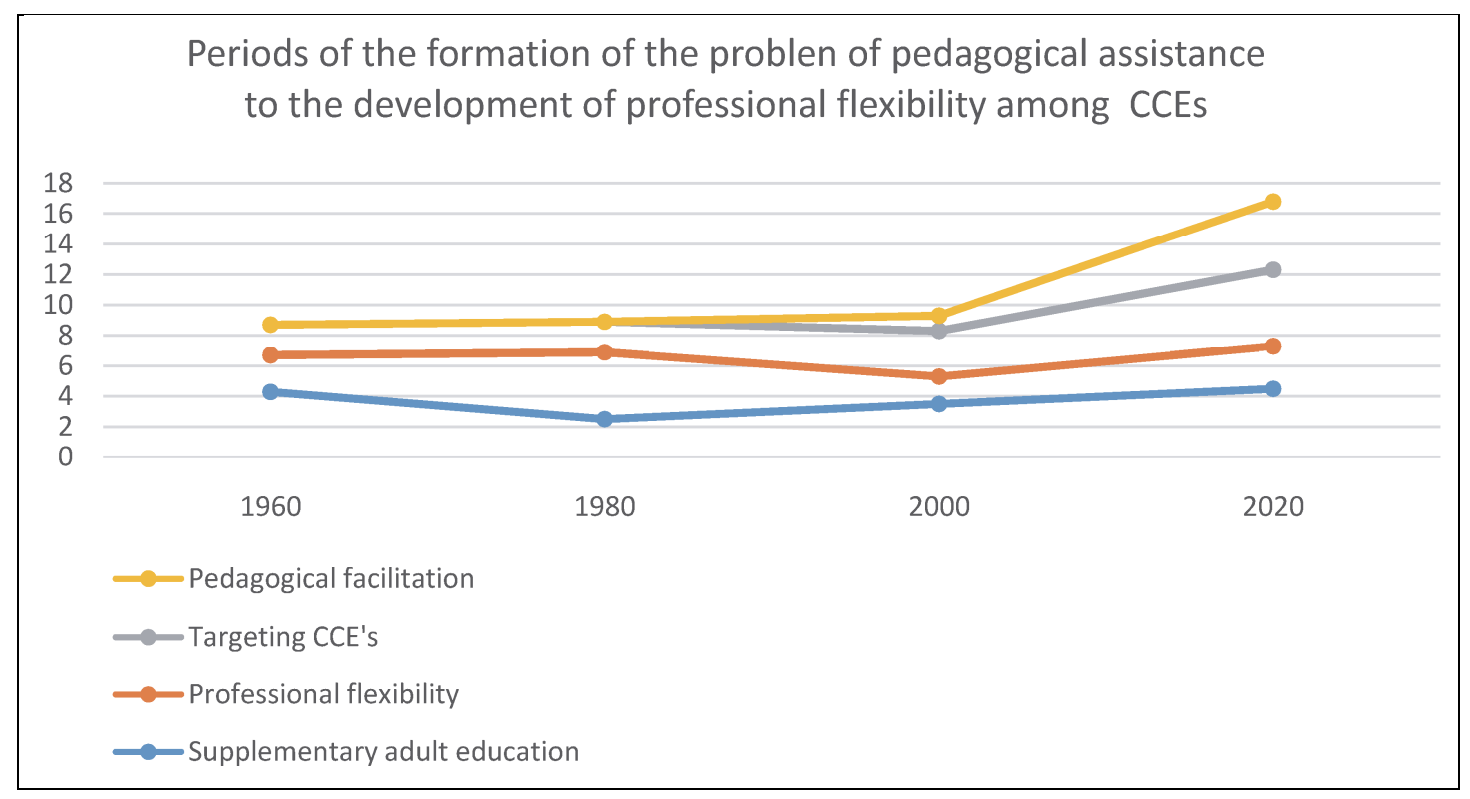

Fig. 1. Historical timeline 
The historical retrospective is established on the following research subjects: "supplementary adult education"; "professional flexibility"; "pedagogical facilitation"; "targeting company's chief executives". All these subjects are considered in their historical developmental aspects.

The first period: from the beginning of the 60 s to the end of the 80 s of the XX century.

This period is characterized by the stable development of our country, which practically restored the national economy destroyed during the Great Patriotic War, reached the pre-war population, and strategically focused on improving the quality of life as a whole [26].

During this period, there were significant scientific changes. The table 1 demonstrates the main epochs from the $60 \mathrm{~s}$ to the end of the $80 \mathrm{~s}$, acceding to the development in the next subjects, as "supplementary adult education"; "professional flexibility"; "pedagogical facilitation"; "targeting CCEs".

At this point in the accepted interpretation of R.V. Rajabova [26] "continuing education" we note conscious activities that complement each other and occur both within the general education system and outside it at different periods of life. The distinctive feature of this doctrine is the activity aimed at the acquisition of knowledge of the development of all aspects and abilities of the person, including the ability to learn and prepare for various social and professional responsibilities and participate in the social development of society.

The results of N.A. Menchinskaya's research (1966) allow us to consider this phenomenon not only as the ability to move from one action to another, but also as the possibility of multidimensional reflection of task conditions, which significantly extends the characteristic of flexibility. The author singled out the following manifestations of flexible thinking: 1) the problem approach to a task as a problem, expedient variation of modes of action; 2) ease of readjustment of knowledge or skills and their systems in accordance with the changed conditions; 3) switching ability, or ease of transition from one mode of action to another [18].

This trend is an important step in solving our problem because education is seen not only as a process of acquiring professional skills but also includes the training of professionals who are ready to solve social problems. Nevertheless, in the theory and practice of Soviet education the notion of "professional flexibility" is not considered when describing the professional skills of managers. At the same time, there was also no interest in research dedicated to a comprehensive study of the phenomenon of "pedagogical assistance".

In sum, it should be remarked that during the first period it is possible to record a scientific and practical interest in all components of the identified problem. However, the study of the phenomenon we are interested in is spontaneous and fragmented and is not yet the subject of a comprehensive study due to such reasons as a tense political and economic situation, lack of social need for leadership training, with professional flexibility, lack of theoretical and methodological basis for an integrative study of the problem.

The first period: from the beginning of the 60 s to the end of the 80 s of the $X X$

Table 1

\begin{tabular}{|l|l|}
\hline \multicolumn{1}{|c|}{ Research subjects } & \multicolumn{1}{c|}{ Initial points } \\
\hline Pedagogical facilitation & $\begin{array}{l}\text { Elements emerge both in the field of general pedagogical ideas and in } \\
\text { the organization of their methodological support }\end{array}$ \\
\hline Professional flexibility & $\begin{array}{l}\text { The appearance of the definition of "competence". } \\
\text { For the first time this phenomenon was characterized as the possibility of } \\
\text { multidimensional reflection of task conditions, which significantly extends } \\
\text { the characteristic of flexibility [31] }\end{array}$ \\
\hline Supplementary adult education & $\begin{array}{l}\text { Sustainable functioning of the system of higher and additional education; } \\
\text { the beginning of the process of deploying a network of structural subdivi- } \\
\text { sions of higher education institutions, providing professional development } \\
\text { and retraining of specialists, including management staff }\end{array}$ \\
\hline Targeting CCEs & $\begin{array}{l}\text { Economic management reforms; } \\
\text { approved standard, according to which all managers and specialists had to } \\
\text { improve their skills at least once in five years. On improvement of the system } \\
\text { of professional development of managers and specialists of industry, con- } \\
\text { struction, transport, communication, and trade; } \\
\text { emergence and comprehension of the concept of continuous education as } \\
\text { formulated by UNESCO in 1984 }\end{array}$ \\
\hline
\end{tabular}




\section{Непрерывное образование в течение жизни...}

The second period: from the late 80 s of the XX century to the early 2000 s.

This stage is characterized by significant transformations in all spheres of life of our country, destruction of the Soviet system of national economy management, changes in state policy, public relations, and national ideology. This was the period of the deepest crisis of the Russian education system and its subsequent reform.

Various types of professional competence have taken a special place in research, including the interest in the professional competence of a manager. It has been studied in various types (A.M. Omarov, V.G. Zazykin, A.P. Chernyshev, A.P. Sitnikov, A.A. Derkach, I.V. Elshina), the psychological characteristics of a leader (L.D. Kudryashova, M.V Maksimovskaya), managerial activity itself (A.L. Zhuravlev, V.F. Rubakhin, O.E. Anisimov, A.A. Derkach and others).

Gradually developing conceptual positions of scientists characterizing the role of additional professional education as a social institution, not only preparing personnel for the national economy but also forming the intellectual and creative potential of society. During this period, interest in the scientific study of all aspects of the problem we have identified has been restored, and revision of existing scientific results has begun, taking into account new realities and conditions of Russian professional education, which gave a new impetus to the development and solution of the problem we have identified [22].
The 1990s can be seen as the beginning of the transition to a structural-functional model of methodological services, whose target and value priorities are the implementation of a person-centered (developmental) approach, the strengthening of subjectivity and all participants in the educational process, the adaptability of organizational forms and products of the methodological service to the changing conditions of professional education [9].

This period represents the following important developments relating to our identified research components. The table 2 shows historical events of the development of the following subjects: "supplementary adult education"; "professional flexibility"; "pedagogical facilitation"; "targeting CCEs".

Summing up the general results of the second period, it can be indicated that the systematic study of these aspects led to the emergence of new scientific interests to the studied parameters of our research problem.

The third period: from the early 2000s to the present. This stage is characterized by broad global and integration processes of different orientation, the orientation of European states and the U.S. to international cooperation: the prevalence of methodological ideas that justify the interaction of individuals and society, the active provision of additional paid educational services in state and private educational institutions in demand by students [25].

The second period: from the late 80 s of the $X X$ century to the early 2000 s

\begin{tabular}{|l|l|}
\hline \multicolumn{1}{|c|}{ Research subjects } & \multicolumn{1}{c|}{ Initial points } \\
\hline Pedagogical facilitation & $\begin{array}{l}\text { Orientation of the educational process towards personal development in } \\
\text { the conditions of continuous education [4]; } \\
\text { changing the types and forms of communication in the scientific community } \\
\text { and forming an Internet environment [5] }\end{array}$ \\
\hline Professional flexibility & $\begin{array}{l}\text { Beginning of scientific interest in researches connected with the problems } \\
\text { of forming different competencies; } \\
\text { the onset of democratic changes in the country has freed the process of edu- } \\
\text { cation and training from uniformity and unilateralism [3] }\end{array}$ \\
\hline Supplementary adult education & $\begin{array}{l}\text { Allocation of an independent institutional basis for the "system of additional } \\
\text { professional education", enrichment of methods, principles, and forms of } \\
\text { education. } \\
\text { The adoption of the Law of the Russian Federation N 3266-1 "On educa- } \\
\text { tion", which was the starting point for the implementation of the competence } \\
\text { approach in the education system; } \\
\text { the dominating positions of additional technical education were replaced } \\
\text { by the spectrum of educational programs of humanitarian knowledge }\end{array}$ \\
\hline Targeting CCEs & $\begin{array}{l}\text { Emergence of interest in Western management models; } \\
\text { defined the target activity of the modern head of an educational institution } \\
\text { as a managerial and pedagogical one requiring professional training [9] }\end{array}$ \\
\hline
\end{tabular}


The role of the system of additional professional education in the current conditions, in the formation and development of human resources in Russia, which is identified in the "Law on Education in the Russian Federation", was defined (approved on December 29, 2012, N 273-FZ), where Article 76 "Additional education" states that additional vocational education is aimed at meeting the educational and professional needs, professional development of the person, ensuring compliance with the changing conditions of professional activity and social environment [11].

Simultaneously with the Russian government decree on the approval of the state program "Development of Education for 2013-2020", the "Law on Education in the Russian Federation" N 273-FZ of 01.09.13, where vocational education is considered "as the acquisition of professional competence by persons of different ages" is developed and approved [11].

In 2004, A.A. Dergach introduced the concept of "cognitive abilities of manager" for the first time and noted the importance of this factor for the success of the professional activity [8].

Thus, the third stage of the problem we are investigating identified on table 3 .

The results recognize the importance of these transformations have changed the field of a pedagogical science, which allows us to state that the third period of formation of the studied problem characterizes by extensive experience in solving all aspects. These changes, which affected the process of organization and content of professional education, led to the expansion of scientific and pedagogical research of the phenomenon of "professional competence".

\section{Results and Discussion}

The purpose of this study was to analyze the historical paradigms to identify prerequisites in the study of pedagogical assistance of professional flexibility formation of company's chief executives in learning a foreign language. This analysis has led us to conclude that the problem we have identified and investigated has a long history of formation and is currently relevant, complex but underdeveloped.

The findings acknowledge the importance of all the historical and scientific transformations that have changed the field of educational science. This allowed us to state that the third period of formation of the problem under study was characterized by a great accumulation of experience in solving all the subjects of our study. These changes influenced the process of organi zation and content of professional education, led to the expansion of scientific and pedagogical research on the phenomenon of "professional flexibility".

Even though the prerequisites are identified, the transformations that have changed the field of pedagogical science in the formation of the problem we are studying, but research on the problem of pedagogical assistance to the development of company's chief executives professional flexibility is insufficient.

Here we should also note the role of other scholars. For example, studying the historical aspect of the emergence of the concept of lifelong learning, V.G. Osipov distinguished five

The third period: from the early 2000 s to the present

Table 3

\begin{tabular}{|l|l|}
\hline \multicolumn{1}{|c|}{ Research subjects } & \multicolumn{1}{c|}{ Initial points } \\
\hline Pedagogical facilitation & $\begin{array}{l}\text { The emergence of innovative general pedagogical and methodological ideas } \\
\text { in vocational training; } \\
\text { The introduction of monitoring of the efficiency of educational organiza- } \\
\text { tions [23] }\end{array}$ \\
\hline Professional flexibility & $\begin{array}{l}\text { Transition to competency-based education [21]; } \\
\text { increasing the number of researches devoted to the problem of professional } \\
\text { competence formation [6] }\end{array}$ \\
\hline Supplementary adult education & $\begin{array}{l}\text { Russia's entry into the Bologna Process [17]; } \\
\text { the transition in 2011 to a two-level system of training in higher education; } \\
\text { development and adoption of the new law "On education in the Russian } \\
\text { Federation" [11] }\end{array}$ \\
\hline Targeting CCEs & $\begin{array}{l}\text { Adoption of standards that determine the volume, structure, and content of } \\
\text { formed knowledge, skills, and abilities of graduates of higher education in- } \\
\text { stitutions that become bachelors, specialists, or masters of the corresponding } \\
\text { directions [26]; } \\
\text { modernization of the Russian education system }\end{array}$ \\
\hline
\end{tabular}




\section{Непрерывное образование в течение жизни...}

stages of historical periods, but these stages did not cover the period of the 21 st century [24].

It is quite surprising that the transition to "the competence paradigm of the entire education system in Russia and the introduction of Professional Standards that impart a practice-oriented character to training in professional educational organizations serves as a stimulating tool" [24].

This highlights that during our analysis a significant need for theoretical, scientific, methodological, and technological development of effective methods of pedagogical assistance to the development of professional competence among top managers is revealed. The analysis of the literature has shown that the period before 1960s is considered a preparatory one. It created social, scientific, and practical conditions for pedagogical assistance of professional flexibility formation among company's chief executives [32].

The implications of this study for the contribution of educational research are developed through a detailed discussion of recent research on professional flexibility.

\section{Conclusion}

In a renew economy, the commitment for qualitative of professional flexibility formation in training of company's chief executives has increased.

In this study, we have analyzed the initial historical background for further structuring and improving educational practices to develop professional flexibility formation company's chief executives.

In conclusion, we can state that the historiography of the problem under study includes three main periods: the 1st one is from the beginning of the $60 \mathrm{~s}$ to the end of the $80 \mathrm{~s}$ of the XX century; the $2^{\text {nd }}$ period is from the end of the 80 s of the XX century to the beginning of the 2000s; the $3^{\text {rd }}$ period is from the beginning of the 2000 s up to the present.

The period before 1960 is considered as a preparatory one, which creates social, scientific, and practical conditions for becoming the problem currently important. The first period puts the basis for setting the problem and sparks the scientific and practical interest in all components of the identified problem. However, the study of the phenomenon is rather spontaneous and fragmented and is not yet the subject of a comprehensive study due to political, economic, social and methodological reasons. The second period is characterized by such trends as systematic study of these aspects, which led to the emergence of new scientific interests to the parameters of our research problem. The third period of formation of the problem under study is defined by extensive experience in solving all aspects. In addition, as consequences, these changes have influenced the process of organization and content of professional education, which led to the expansion of scientific and pedagogical research of the phenomenon of "professional flexibility". It has become comprehensive and needs further research.

While all the periods have been highlighted and substantiated for this study, there are limitations in general. These limitations lie in the fact that the problem of our study is poorly researched in terms of historiography.

Future work will concentrate on the construction of the conceptual-categorical field of the study "Pedagogical assistance of professional flexibility formation among company's chief executives".

\section{References}

1. Artem yeva E.Y., Strelkov Y.K. [Professional Component of Peace Image]. Myshlenie $i$ obshchenie: aktivnoe vzaimodeystvie s mirom: sb. nauch. trudov [Thinking and Communicating: Active Interaction with the World. Collection of Scientific Works]. Yaroslavl, Yaroslavskiy Gosudarstvennyy Universitet, 1988, pp.67-84. (in Russ.)

2. Asmakovets E.S. Psikhologicheskie faktory $i$ usloviya razvitiya emotsional'noy gibkosti uchitelya. Avtoref. kand. dis. [Psychological Factors and Conditions of Development of Teacher's Emotional Flexibility. Abstract of kand. diss.]. Moscow, 2000. 123 p.

3. Avetisyan K.A. Psichologicheskoe soderzhanie $i$ usloviya dlya razvitiya povedencheskoy gibkosti uchitelya. Dis. kand. psych. nauk [Psychological Content and Conditions for Development of teacher's Behavioural Flexibility. Diss. kand. (Psychology)]. Moscow, 2001. 176 p.

4. Bespal'ko V.P. Pedagogika i progressivnye tekhnologii obucheniya [Pedagogy and Advanced Learning Technologies]. Moscow, Pedagogy Publ., 1995. 336 p.

5. Borisenkov V. P. [Strategy of Educational Reforms in Russia (1985-2006)]. Pedagogy, 2007, no. 7, pp. 3-16. (in Russ).

6. Bryukhova N. G. [Psychological Counseling on Problems of Life Path of Personal and Professional Development and Improvement of Specialist in the System of Professions "Person - 
Personality"]. Vozrastnaya $i$ pedagogicheskaya psichologiya: mechanizmy $i$ usloviya psichicheskogo razvitiya I formirivaniya lichnosti [Age and Educational Psychology: Mechanisms and Conditions of Mental Development and Personality Formation. Novosibirsk, Publishing House], 2013. pp. 95-150. (in Russ).

7. Dergach A.A. Akmeologicheskiye osnovy professional'nogo razvitiya [Acmeological Class Pink Professionalism]. Moscow, MPSI Publ., 2004. $135 \mathrm{p}$.

8. Derkach A.A. Formirovaniye i razvitiye professional'nogo masterstva rukovodyashchikh kadrov: sotsial'no-psikhologicheskiy trening $i$ prikladnye psikhotekhnologii [Formation and Development of Professional Skills of Management Personnel: Socio-Psychological Training and Applied Psychotechnologies]. Moscow, Luch Publ., 1993. 214 p.

9. Deyev E.E. Razvitiye nachal'nogo professional'nogo obrazovaniya $v$ Rossii: uchebnoye posobiye dlya vuzov [Development of Initial Vocational Education in Russia: A Textbook for Higher Education Institutions]. Moscow, Yurayt Publishing House Publ., 2021. 285p.

10. Ermakova E.S. Psikhologicheskiye zakonomernosti formirovaniya gibkosti produktivnogo myshleniya u detey doshkol'nogo i mladshego shkol'nogo vozrasta. Dis. dokt. psikhol. nauk [Psychological Rules of Forming of Flexible and Productive Thinking Among the Preschool Children and Primary School Pupils. Dis. doct. (Psychology)]. Moscow, 2006. 247 p.

11. Federal'nyy zakon "Ob obrazovanii $v$ Rossiyskoy Federatsii" ot 29.12.2012 N 273-FZ (poslednyaya redaktsiya) [Federal Law "On Education in the Russian Federation" dated December 29, 2012 N 273-Ф3]. Available at: http:// www.consultant.ru/document/cons_doc_LAW 140174 (accessed 18.02.2021).

12. Kalmykova Z.I. Produktivnoe myshlenie kak osnova obuchennosti [Productive Thinking as the Basis of Learning]. Moscow, Pedagogy Publ., 1981. $168 \mathrm{p}$.

13. Kornilova T.V. Risk i prinyatiye resheniy: psikhologiya neopredelennosti [Risk and Decision-Making: Psychology of Uncertainty]. Available at: http://www.rfh.ru/downloads/ Books/144693004.pdf (accessed 05.12.2020).

14. Kotlyarova I.O., Serikov G.N. [Assertion of the Retrospective and Ways to Solve of the Pedagogical Problem]. Bulletin of the South Ural State University. Ser. Education. Pedagogy, 2012, no. 4 (263), pp. 12-17. (in Russ.)
15. Luk A.N. Myshlenie $i$ tvorchestvo [Thinking and Creativity]. Moscow, Politizdat Publ., 1976. 144 p.

16. Mal'tseva A.M. [Personal Flexibility and Methods of its Diagnosis]. World of Science, Culture, Education, 2012, no. 2 (33), pp. 91-93. (in Russ.)

17. Medvedev S. [Bologna Process, Russia and Globalization]. Higher Education in Russia, 2006, no. 3, pp. 31-36. (in Russ.)

18. Menchinskaya, N.A. [Thinking While Learning] Obuchenie i razvitie. Materialy $k$ simpoziumu [Training and Development. Materials for the Symposium], 1996, pp. 5-8.

19. Mitina L.M. Psikhologiya truda i professional'nogo razvitiya pedagoga [Psychology of Work and Professional Development of a Teacher]. Moscow, Academy Publ., 2004. 320 p.

20. Mitina L.M. Uchitel' kak lichnost' i professional: psikhologicheskiye problemy [The Teacher as a Person and Professional (Psychological Problems)]. Moscow, Delo Publ., 1994. $216 \mathrm{p}$.

21. Morosanova V.I. Individual'nyy stil' samoregulyatsii: fenomen, struktura $i$ funktsii $v$ proizvol'noy aktivnosti cheloveka [Individual Style of Self-regulation Phenomenon Structure and Function in Voluntary Human Activity]. Moscow, Nauka Publ., 2001. 192 p.

22. Nayn A.Ya., Morosanova A.Y. Problemy razvitiya professional'nogo obrazovaniya: regional'nyy aspekt [Problems of Vocational Education Development: Regional Aspect]. Chelyabinsk, 1998. $87 \mathrm{p}$.

23. Oleynikova O.N., Muravyova A.A., Konovalova J.V., Sartakova E.V. Modul'nye tekhnologii i razrabotka obrazovatel'nykh programm: uchebnik [Modular Technology and Development of Educational Programs: a Textbook]. Moscow, Alpha-M. Publ., 2010. 256 p.

24. Osipov V.G. Sotsial'no-filosofskiy analiz sovremennoy kontseptsii obrazovaniya na protyazhenii vsey zhizni [Socio-Philosophical Analysis of the Modern Conception of Lifelong Learning]. Yerevan, Academy of Sciences of the Armenian SSR Publ., 1989. 216 p.

25. Radzhabova P.V. [Continuous Education is a Fundamental Principle of Upbringing and Education of Personality]. Humanities and Social Sciences, 2016, no. 3. pp. 166-177.

26. Ratkovskiy I.S. Istoriya Sovetskoy Rossii [History of Soviet Russia]. St. Petersburg, Lan Publ., 2001. 416 p.

27. Todysheva T.Yu. [Personal Flexibility 


\title{
Непрерывное образование в течение жизни...
}

in Professional Life]. Bulletin of the Buryat State University, 2010, no. 5, pp. 84-88. (in Russ.)

28. Valieva F.I. [Social Support as a Factor Contributing to the Improvement of Professional Stress Tolerance of Teachers]. Scientific and Technical Bulletin of the St. Petersburg State Polytechnic University. Humanities and social sciences, 2010, no. 1(105), pp. 121-127. (in Russ).

29. Zalevski G.V. Lichnost' i fiksirovannye formy povedeniya [Personality and Fixed Forms of Behaviour]. Moscow, IP RAN Publ., 2007. 336 p.

30. Zavalishina D.N. Prakticheskoye myshleniye: spetsifika i problemy razvitiya [Practical
Thinking: Specifics and Problems of Development]. Moscow, Institut psikhologii RAN Publ., 2005. 233p.

31. Zavalkevich L.E., Kosik V.V. [Flexibility as a Background of Manager's Effectiveness]. Staff, 2002, vol. 10, pp. 119-126. (in Russ.)

32. Zhurakovsky G.E. Ocherki po istorii antichnoy pedagogiki [Essays on the History of Ancient Pedagogy]. Moscow, APN of the RSFSR Publ., 1963. 512 p.

33. Yakovleva N.O. [Historiography of a Scientific Problem as a Result of Historical and Pedagogical Analysis]. Modern Higher School: Innovative aspect, 2009, no. 4, pp. 60-66.

Received 15 January 2021

Удк 378.046.4 + 005.61

DOI: $10.14529 /$ ped210204

\section{РЕТРОСПЕКТИВНЫЙ АНАЛИЗ ПЕДАГОГИЧЕСКОГО СОДЕЙСТВИЯ РАЗВИТИЯ ПРОФЕССИОНАЛЬНОЙ ГИБКОСТИ У РУКОВОДИТЕЛЕЙ}

\author{
Л.А. Сюзюмова \\ Южно-Уральский государственный университет, г. Челябинск, Россия
}

\begin{abstract}
В условиях современной экономической ситуации растет потребность в качественном обучении руководителей с высоким уровнем профессиональной гибкости. Цель данного исследования выявить социально-исторические и теоретико-педагогические предпосылки становления и развития данной проблемы. В исследовании анализируются исходные данные для дальнейшего структурирования и совершенствования образовательной практики с целью развития профессиональной гибкости у руководителей. Проблема педагогического содействия развитию профессиональной гибкости у руководителей высшего звена анализируется с помощью ретроспективного анализа. Были идентифицированы четыре содержательных компонента исследования: «дополнительное образование взрослых»; «формирование профессиональной гибкости»; «педагогическое содействие»; «актуальность роли руководителя», которые рассматриваются в аспекте исторического развития. Представляя историографию проблемы, автор выделяет ряд периодов. Выявлены исторические периоды развития проблемы развитию профессиональной гибкости у руководителей: 1-й с начала 60-х годов до конца 80-х годов XX века; 2-й - с конца 80-х годов XX века до начала 2000-х годов; 3-й - с начала 2000-х годов до настоящего времени. Период до 1960-х годов считается подготовительным. Он создал социальные, научные и практические условия для педагогического содействия развитию профессиональной гибкости руководителей.

Ключевые слова: ретроспективный анализ, историография, отправная точка, ключевые компоненты проблемы, профессиональная гибкость, педагогическое содействие, руководители.
\end{abstract}

\section{Литература}

1. Артемьева, Е.Ю. Профессиональная составляющая образа мира / Е.Ю. Артемьева, Ю.К. Стрелков // Мышление и общение: активное взаимодействие с миром: сб. науч. тр. - Ярославль: ЯрГУ, 1988. - С. 67-84.

2. Асмаковеи, Е.С. Психологические факторы и условия развития эмоииональной гибкости учителя: автореф. дис. ... канд. псих. наук / Е.С. Асмаковец. - М., 2000. - 123 с. 
3. Аветисян, К.А. Психологическое содержание и условия для развития поведенческой гибкости учителя: дис. ... канд. психол. наук / К.А. Аветисян. - М., 2001. - 176 c.

4. Беспалько, В.П. Педагогика и прогрессивные технологии обучения / В.П. Беспалько. - М.: Изд-во ин-та проф. образования М-ва образования России, 1995. - 336 с.

5. Борисенков, В.П. Стратегия образовательных реформ в России (1985-2006 г2.) / В.П. Борисенков. - Педагогика. - 2006. - № 7. - C. 3-16.

6. Брюхова, Н.Г. Психологическое консультирование по проблемам жизненного пути личностного и профессионального развития и совершенствования специалиста в системе профессий «человек - личность» / Н.Г. Брюхова // Возрастная и педагогическая психология: механизмы и условия психического развития и формирования личности. - Новосибирск: Издат. дом ЦРНС, 2013. - C. 95-150.

7. Дергач, А.А. Акмеологические основы профессионального развития / А.А. Дергач. - М.: Издат. дом Моск. психол.-сочиал. ин-та, 2004. - 752 c.

8. Деркач, А.А. Формирование и развитие профессионального мастерства руководящих кадров: социально-психологический тренинг и прикладные психотехнологии / А.А. Деркач, А.П. Ситников. - М.: Луч, 1993. -75 с.

9. Деев, Е.Е. Развитие начального профессионального образования в России: учеб. пособие для вузов / Е.Е. Деев. - М.: Юрайт, 2021. - 285 с.

10. Ермакова, Е.С. Психологические закономерности формирования гибкости продуктивного мышления у детей дошкольного и младшего школьного возраста: дис. ... д-ра психол. наук I Е.С. Ермакова. - М., 2006. - 247 с.

11. Федеральный закон «Об образовании в Российской Федерации» от 29.12 .2012 № 273-Ф3. - http://www.consultant.ru/document/cons_doc_LAW_140174/(дата обращчения: 18.02.2021).

12. Калмыкова, З.И. Продуктивное мышление как основа обученности / 3.И. Калмыкова. М.: Педагогика, 1981. - 200 c.

13. Корнилова, Т.В. Риск и принятие решений: психология неопределенности. - http://www. rfh.ru/downloads/Books/144693004.pdf (дата обращения: 05.12.2020).

14. Котлярова, И.О. Констатация ретроспективы и состояния решения педагогической проблемы / И.О. Котлярова, Г.Н. Сериков // Вестник ЮУрГУ. Серия «Образование. Педагогические науки». - 2012. - № 4 (263). - C. 12-17.

15. Лук, А.Н. Мышление и творчество / А.Н. Лук. - М.: Политиздат, 1976. - 144 c.

16. Мальцева, А.М. Личностная гибкость и методы ее диагностики / А.М. Мальцева // Мир науки, культуры, образования. - 2012. - № 2 (33). - С. 91-93.

17. Медведев, С. Болонский проиесс, Россия и глобализаиия / С. Медведев // Высшее образование в России. - 2006. - № 3. - С. 31-36.

18. Менчинская, Н.А. Обучение и умственное развитие / Н.А. Менчинская // Обучение и развитие: материаль к симпозиуму. - М.: Просвещение, 1966. - С. 5-8.

19. Митина, Л.М. Психология труда и профессионального развития педагога / Л.М. Митина. - М.: Академия, 2004. - 320 c.

20. Митина, Л.М. Учитель как личность и профессионал: психологические проблемы / Л.М. Митина. - М.: Дело, 1994. - 216 с.

21. Моросанова, В.И. Индивидуальный стиль саморегулящии: феномен, структура и функции в произвольной активности человека / В.И. Моросанова. - М.: Наука, 2001. - 192 c.

22. Найн, А.Я. Проблемы развития профессионального образования: региональный аспект / А.Я. Найн, Ф.Н. Клюев. - Челябинск: Изд-во Ин-та развития проф. образования, 1998. -87 с.

23. Модульные технологии и разработка образовательных программ: учеб. / О.Н. Олейникова, А.А. Муравьева, Ю.В. Коновалова Ю.В. и др. - 2-е изд. - М.: Альфа-М: ИНФРА-М, 2010. $256 \mathrm{c.}$

24. Осипов, В.Г. Социально-философский анализ современной концепции образования на протяжении всей жизни / В.Г. Осипов. - Ереван: Академия наук Армянской ССР, 1989. - 216 с.

25. Раджабова, Р.В. Непрерывное образование является фундаментальным принципом воспитания и образования личности / Р.В. Раджабова // Гуманитар. и обществ. науки. - 2016. № 3. - C. 166-177. 
26. Ратковский, И.С. История Советской России / И.С. Ратковский, М.В. Ходяков. - СПб.: Лан, 2001. $-416 c$.

27. Тодышева, Т.Ю. Личностная гибкость в профессиональной деятельности / Т.Ю. Тодымева // Вестник Бурят. гос. ун-та. - 2010. - № 5. - С. 84-88.

28. Валиева, Ф.И. Социальная поддержка как фактор, способствуюший профессиональной стрессоустойчивости преподавателей / Ф.И. Валиева // Науч.-техн. вестник С.-Петерб. гос. политехн. ун-та. Гуманитар. и социал. науки. - 2010. - № 1 (105). - С. 121-127.

29. Залевский, Г.В. Личность и фиксированные формы поведения / Г.В. Залевский. - М.: ИП PAH, 2007. $-336 c$.

30. Завалишина, Д.Н. Практическое мышление: специфика и проблемы развития / Д.Н. Завалишина. - М.: Изд-во «Институт психологии РАН», 2005. - 233 с.

31. Завалкевич, Л.Э. Гибкость как предпосылка эффективности менеджера / Л.Э. Завалкевич, В.В. Косик // Персонал. - 2002. - № 10. - С. 62-65.

32. Жураковский, Г.Е. Очерки по истории античной педагогики / Г.Е. Жураковский. - М.: Изд-во АПН РСФСР, 1963. - $512 \mathrm{c}$.

33. Яковлева, Н.О. Историография научной проблемь как результат историкопедагогического анализа / Н.О. Яковлева // Современная высшая школа: Инноваџионный аспект. 2009. - № 4. - C. 60-66.

Сюзюмова Людмила Анатольевна, аспирант кафедры безопасности жизнедеятельности, Южно-Уральский государственный университет, г. Челябинск, syuzyumovala@gmail.com.

Поступила в редакцию 15 января 20212.

\section{ОБРАЗЕЦ ЦИТИРОВАНИЯ}

Syuzyumova, L.A. Retrospective Analysis of Pedagogical Assistance to the Formation of Professional Flexibility of Chief Executives / L.A. Syuzyumova // Вестник ЮУрГУ. Серия «Образование. Педагогические науки». - 2021. T. 13, № 2. - C. 42-52. DOI: 10.14529/ped210204

\section{FOR CITATION}

Syuzyumova L.A. Retrospective Analysis of Pedagogical Assistance to the Formation of Professional Flexibility of Chief Executives. Bulletin of the South Ural State University. Ser. Education. Educational Sciences. 2021, vol. 13, no. 2, pp. 42-52. DOI: $10.14529 /$ ped 210204 